\title{
Effect of Different Honey Concentrations on Survival, Longevity and Reproduction of Trichospilus pupivorus (Hymenoptera: Eulophidae), a Parasitoid of Coconut Black-Headed Caterpillar, Opisina arenosella (Lepidoptera: Oecophoridae)
}

\author{
Nor Ahya Mahadi ${ }^{1}$, Tajul Ariffin Aziz Yusof ${ }^{1} \&$ Mazidah Mat ${ }^{2}$ \\ ${ }^{1}$ Industrial Crops Research Center, Malaysian Agriculture Research and Development Institute, Bagan Datuk, \\ Perak, Malaysia \\ ${ }^{2}$ Industrial Crops Research Center, Malaysian Agriculture Research and Development Institute, MARDI \\ Headquarter, Serdang, Selangor, Malaysia \\ Correspondence: Nor Ahya Mahadi, Industrial Crops Research Center, Malaysian Agriculture Research and \\ Development Institute, Jalan Sungai Dulang, 36307 Bagan Datuk, Perak, Malaysia. Tel: 605-648-9242. E-mail: \\ ahya@mardi.gov.my
}

Received: June 8, 2020

Accepted: August 10, 2020

Online Published: September 15, 2020

doi:10.5539/jas.v12n10p57

URL: https://doi.org/10.5539/jas.v12n10p57

\begin{abstract}
Many coconut producing countries in Asia are facing a serious infestation of Opisina arenosella (Lepidoptera: Oecophoridae) or commonly called the coconut black-headed caterpillar. Recently, the pest has been detected in the coconut (Cocos nucifera) planting area in Pahang, Malaysia. Thus, an initiative to manage the pest by using parasitoids has been started with a study on the effects of diet on survival, longevity and reproduction of naturally occurred parasitoid known as Trichospilus pupivorus (Hymenoptera: Eulophidae). The aim of this study was to identify suitable concentrations of honey that can be used in developing its rearing technique. Two independent experiments were conducted, i.e., a) survival and longevity study; and b) reproduction study. In each study, different honey concentrations were tested on ten (eight replications) and one (five replications) female parasitoids respectively. $30 \%$ honey concentrations resulted in high survival rate of the adult during early life with relatively prolonged longevity up to $6.0 \pm 0.19$ days and significantly produced the highest number of progenies (105.4 \pm 0.81$)$. The lowest survival rate was given by $60 \%$ honey and significant longevity up to $6.5 \pm 0.33$ days with no progenies. Further studies on other plausible factors affecting the reproduction and fitness of progenies should also be investigated to ensure efficient rearing techniques.
\end{abstract}

Keywords: Trichospilus pupivorus, Opisina arenosella, Cocos nucifera, diet, longevity and reproduction, pupal parasitoid

\section{Introduction}

Coconut (Cocos nucifera) which is also known as the tree of life is one of the most important commodities in Malaysia with total production of 527,729 metric tonne in 2019 (DOA Malaysia, 2019, p. 20) and has been listed as one of the new wealth resources for the country. Currently, the number of coconut planters in Malaysia has increased from 63,550 in 2017 (DOA Malaysia, 2018, p. 3) to 64,139 in 2018 (DOA Malaysia, 2019, p. 3). However, this positive trend has also caused problems of coconut insect pest infestations which later induced yield reduction.

Opisina arenosella (Lepidoptera: Oecophoridae) or commonly called the coconut black-headed caterpillar is a harmful defoliator of coconut in many coconut producing countries including India, Sri Lanka (Kumara, 2015), Bangladesh (APPPC, 1987), Pakistan, Myanmar (EPPO, 2014), China (Baoqian et al., 2016; Jin et al., 2018), Thailand (DOA Thailand, 2017) and Malaysia (Nor Ahya et al., 2018). Being polyphagous by nature, this pest also found infesting other crops such as oil palm, jackfruit, cashew (Shameer et al., 2017), date palm, and numerous types of ornamental palms (Murthy \& Jalai, 2003). Due to its prolonged larval stage that consists of 7 (male) and 8 (female) larval instars (Kumar, 2002), it could cause up to $45.4 \%$ of crop loss on infested palms in 
the following year after severe $O$. arenosella outbreak (Mohan et al., 2010). The life cycle of the insect reported being completed within 2-3 months under controlled conditions (Santhosh, 1989).

Trichospilus pupivorus (Hymenoptera: Eulophidae) is an endopupal parasitoid of several agricultural pests including Spodoptera litura (Kumar et al., 1995; Sathe \& Chougale, 2014), S. derogate (Sathe \& Chougale, 2014), Thagona tibialis (Tavares et al., 2013), Anticarsia gemmatalis (Tavares et al., 2012), Helicoverpa armigera, Erogolis merione and O. arenosella (Kumar et al., 1995). Although it is a pupal parasitoid, it has been applied to control $O$. arenosella infestations in South India together with other control methods (Anantanarayanan, 1934). Remadevi et al. (1980) claimed that it is efficient to be used as a potential biological control agent of the pest during favorable season. T. pupivorus was first described morphologically by Ferriere (1930) and later followed by Narendran (2011). Many researches on numerous aspects of T. pupivorus has been conducted by earlier researchers since early 1940s which include the biological aspects (Jayaratnam, 1941; Rao et al., 1948; Dharmaraju, 1952; Nirula, 1956), factors affecting its biology (Dharmaraju \& Pradan, 1976) and its hosts range (Tavares et al., 2012; Tavares et al., 2013; Silva et al., 2016). Meanwhile, discussions on the dietary aspect of $T$. pupivorus in relation to its mass rearing is very scarce.

Diet is an important aspect in evaluating parasitoid's performance in terms of survival as well as reproduction and honey have been found to be a beneficial alternative food source for many insects, including parasitoids. For example, Gelis agilis Fabricius (Hymenoptera: Ichneumonidae), a hyperparasitoid of Cotesia glomerata L. (Hymenoptera: Braconidae), produced twice as many progenies when on a diet of honey vs. honey-sugar mimic or non-glucose (Harvey et al., 2012). Jones and Westcott (2002) demonstrated that parasitoids remained alive after 60 days when Trissolcus basalis Wollaston (Hymenoptera: Platygastridae) were given honey and water. A study on female of Cotesia plutellae (Hymenoptera: Braconidae) also showed better longevity when fed with honey (Mitsunaga et al., 2004). However, there is limited knowledge on the effect of honey on T. pupivorus. Therefore, the present study was conducted to understand the effects of different honey concentrations on survival, longevity and reproduction of T. pupivorus honey that can be used in developing its rearing technique.

\section{Materials and Methods}

\subsection{Rearing of Host and Parasitoid}

Colonies of coconut black-headed caterpillar were maintained in a laboratory inside a wooden rearing cage (50 $\mathrm{cm} \times 50 \mathrm{~cm} \times 80 \mathrm{~cm}$ ) covered with muslin cloth for ventilation. They were fed with fresh coconut seedlings aged 1 year old grown in a polybag, which were watered every 2 days. $20 \mathrm{~g}$ NPK green fertilizer was applied to each polybag every three months. The parasitoids were maintained by feeding them with pure honey in glass vials (4 $\mathrm{cm}$ diameter $\times 12 \mathrm{~cm}$ height). They were offered with unparasitized pupae of $O$. arenosella (Nor Ahya et al., 2019) for egg-laying. The parasitized pupae were transferred into other vial and observed for the emergence of progenies. The colonies were maintained under controlled temperature of $30 \pm 3{ }^{\circ} \mathrm{C}, 80 \pm 5 \%$ relative humidity and $12 \mathrm{~h}: 12 \mathrm{~h}$ light and dark illumination.

\subsection{Longevity and Survival Study}

Treatments were prepared by diluting honey into six (6) different concentrations $(10 \%, 20 \%, 30 \%, 40 \%, 50 \%$, and $60 \%$ ) by adding distilled water, and pure distilled water as control. The solutions were later swabbed onto the inner wall of the glass vials using cotton buds to feed the parasitoids. Ten (10) newly emerged female adults of T. pupivorus were collected using an aspirator from a rearing colony and released into the glass vial $(4 \mathrm{~cm}$ diameter $\mathrm{x} 12 \mathrm{~cm}$ height). The glass vial was covered with a muslin cloth for aeration. Data on longevity and survival of parasitoids were recorded daily until all parasitoids died. The experiment was arranged in Complete Randomized Design (CRD) with 8 replications.

\subsection{Reproduction Study}

One (1) newly emerged (within 24 hours) and mated female of T. pupivorus (Kumar et al., 1995) was released into other glass vials of the same size supplied with the above diluted honey concentrations, which replenished every two (2) days. One (1) fresh pupae was introduced into each of the glass vials to be parasitized for 24 hours. The pupae were replaced daily until the parasitoid died. The parasitized pupae were later observed until the emergence of progenies and data collection on the number of progenies that emerged was done. The experiment was arranged in Complete Randomized Design (CRD) with 5 replications.

\subsection{Statistical Analysis}

Survivals of T. pupivorus were estimated using the Kaplan-Meier survival analysis and the log-rank test (Bezerra et al., 2019; Siekmann et al., 2001). Data on longevity and reproduction were subjected to Analysis of Variance (ANOVA) (Salmah et al., 2012; Mashal et al., 2019) after testing for normality using Kolmogorov-Smirnov Test. 
Multiple mean comparisons were done using Fisher's Least Significant Different (LSD) at a 95\% confidence level.

\section{Results}

\subsection{Survival of T. pupivorus}

The survival curves of $T$. pupivorus adults were significantly different between the diets $\left(\chi^{2}=65.97 ; \mathrm{df}=6 ; \mathrm{P}<\right.$ $0.0001)$. Results also revealed that the high survival rate of the parasitoid was recorded for $30 \%$ honey followed by $50 \%, 20 \%, 40 \%, 10 \%$ and $60 \%$ honey (Table 1 and Figure 1) when compared with distilled water. Figure 1 also revealed more than $50 \%$ survival of parasitoid for all treatments (except for those fed with distilled water and $60 \%$ honey), with high survival rate recorded for $30 \%$ honey during the early period even though not significantly different when compared with other honey concentrations (except when compared with $40 \%$ and $60 \%$ honey) (Table 1). The survival for all treatments showed a sudden decline later in the experiment $\left(5^{\text {th }}\right.$ day), and survival curve for $60 \%$ honey started to flatten towards the end of study (Figure 1).

\subsection{Longevity of T. pupivorus}

On the other hand, the longevity of T. pupivorus was significantly affected by different honey concentrations (F $=7.84 ; \mathrm{P}<0.001$ ) with relatively increasing trend (Figure 2 ). Moreover, further analysis shows that the highest longevity obtained was on diet of $60 \%$ honey with 6.5 days longevity followed by $40 \%, 30 \%, 50 \%, 20 \%$ and $10 \%$ honey with $6.0,6.0,5.8,5.6$ and 5.4 days respectively (Table 2 ). The lowest longevity was given by distilled water with 4.1 days. Longevity on $10 \%$ and $20 \%$ honey were statistically the same and it is similar to the case for $30 \%, 40 \%$ and $50 \%$ honey concentrations (Figure 2 and Table 2).

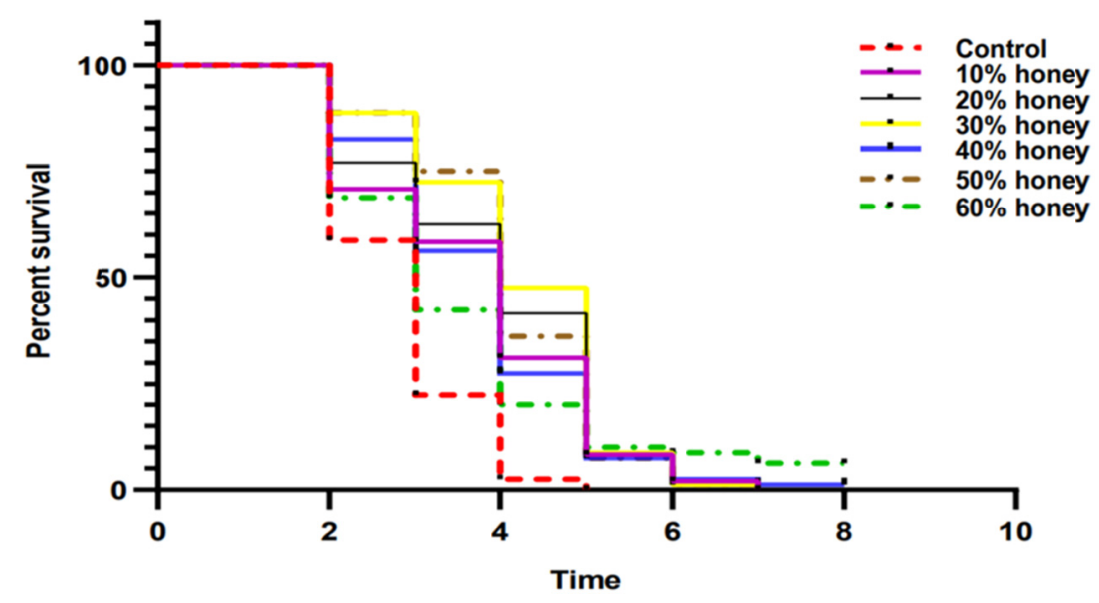

Figure 1. Survival curve of Trichospilus pupivorus female adults fed with distilled water and different honey concentrations in 7 days 
Table 1. Logrank test for comparison of Trichospilus pupivorus female adults' survival on different honey concentrations. Asterisk indicates significant difference in treatments and 'ns' showed no-significant difference computed with $\mathrm{P}=0.05$

\begin{tabular}{llll}
\hline & $\chi^{2}$ & $\mathrm{df}$ & P value \\
\hline $30 \%$ honey $v s$ water & 56.97 & 1 & $<0.0001^{*}$ \\
$50 \%$ honey $v$ water & 52.50 & 1 & $<0.0001^{*}$ \\
$10 \%$ honey $v$ water & 20.45 & 1 & $<0.0001^{*}$ \\
$20 \%$ honey $v$ water & 29.15 & 1 & $<0.0001^{*}$ \\
$40 \%$ honey $v s$ water & 28.56 & 1 & $<0.0001^{*}$ \\
$60 \%$ honey $v s$ water & 12.05 & 1 & $0.0005^{*}$ \\
$30 \%$ honey $v s 60 \%$ honey & 5.788 & 1 & $0.0161^{*}$ \\
$50 \%$ honey $v s 60 \%$ honey & 4.756 & 1 & $0.0292^{*}$ \\
$30 \%$ honey $v s 40 \%$ honey & 4.016 & 1 & 0.0451 \\
$30 \%$ honey $v s 10 \%$ honey & 2.728 & 1 & $0.0984 \mathrm{~ns}$ \\
$40 \%$ honey $v s 50 \%$ honey & 2.330 & 1 & $0.1269 \mathrm{~ns}$ \\
$10 \%$ honey $v s 50 \%$ honey & 1.409 & 1 & $0.2353 \mathrm{~ns}$ \\
$20 \%$ honey $v s 60 \%$ honey & 1.368 & 1 & $0.2421 \mathrm{~ns}$ \\
$20 \%$ honey $v s 40 \%$ honey & 0.6666 & 1 & $0.4142 \mathrm{~ns}$ \\
$20 \%$ honey $v s 30 \%$ honey & 0.5905 & 1 & $0.4422 \mathrm{~ns}$ \\
$40 \%$ honey $v s 60 \%$ honey & 0.5316 & 1 & $0.4659 \mathrm{~ns}$ \\
$10 \%$ honey $v s 20 \%$ honey & 0.5252 & 1 & $0.4686 \mathrm{~ns}$ \\
$30 \%$ honey $v s 50 \%$ honey & 0.4945 & 1 & $0.4819 \mathrm{~ns}$ \\
$10 \%$ honey $v s 60 \%$ honey & 0.1929 & 1 & $0.6605 \mathrm{~ns}$ \\
$20 \%$ honey $v s 50 \%$ honey & 0.07301 & 1 & $0.7870 \mathrm{~ns}$ \\
$10 \%$ honey $v s 40 \%$ honey & 0.0005925 & 1 & $0.9806 \mathrm{~ns}$ \\
\hline
\end{tabular}

Note. Asterisk indicate significant different at $\alpha=0.05$; ns $=$ no significant different.

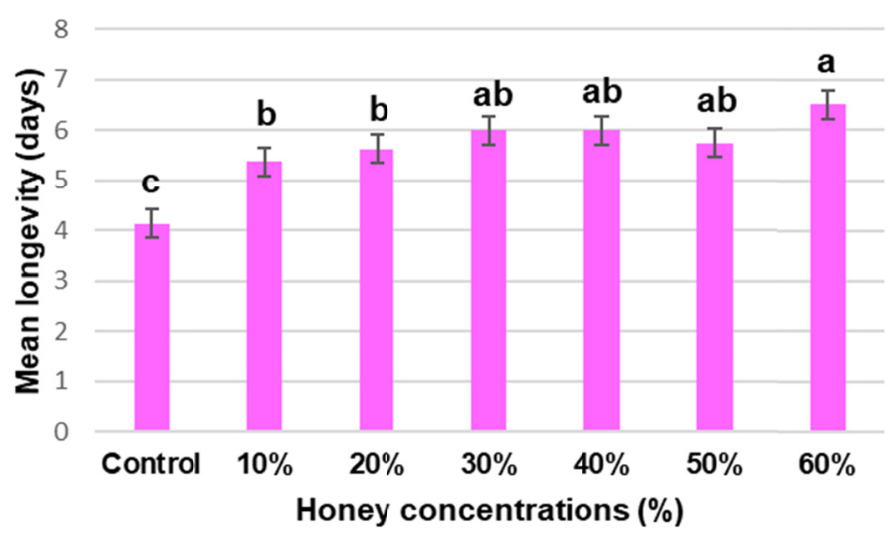

Figure 2. Comparison of different honey concentrations on longevity of Trichospilus pupivorus female adults.

The bars are showing mean value of eight replications. Error bars are showing Standard Error of means. Lettering on bars showing significant difference in treatments and similar letter showed no-significant difference computed with $\mathrm{P}=0.05$ 
Table 2. Mean longevity (days) \pm S.E. of Trichospilus pupivorus female adults on different honey concentrations. Lettering on means showing significant difference in treatments and similar letter showed no-significant difference computed with $\mathrm{P}=0.05$

\begin{tabular}{llc}
\hline \multirow{2}{*}{ Treatments } & \multicolumn{2}{c}{ Longevity } \\
\cline { 2 - 3 } & Mean (Days) & \pm S.E. \\
\hline $60 \%$ honey & $6.50 \mathrm{a}$ & 0.33 \\
$30 \%$ honey & $6.00 \mathrm{ab}$ & 0.19 \\
$40 \%$ honey & $6.00 \mathrm{ab}$ & 0.27 \\
$50 \%$ honey & $5.75 \mathrm{ab}$ & 0.25 \\
$20 \%$ honey & $5.63 \mathrm{~b}$ & 0.26 \\
$10 \%$ honey & $5.38 \mathrm{~b}$ & 0.32 \\
Distilled water & $4.13 \mathrm{c}$ & 0.23 \\
\hline
\end{tabular}

\subsection{Reproduction of T. pupivorus}

Results in Figure 3 shows significant effects of different honey concentrations on progenies emergence $(\mathrm{F}=$ $14.08, \mathrm{P}<0.01)$. The highest number of progenies that emerged in this study was found on $30 \%$ honey $(105.4 \pm 0.81)$ and followed by $20 \%(68.8 \pm 0.68)$. Meanwhile, the effects of $40 \%(50.2 \pm 1.64)$ and $10 \%(31.4 \pm 0.37)$ were similar to the control $(25.0 \pm 0.19) .50 \%(9.8 \pm 1.40)$ and $60 \%$ honey $(0.0)$ were the least (Figure 3$)$.

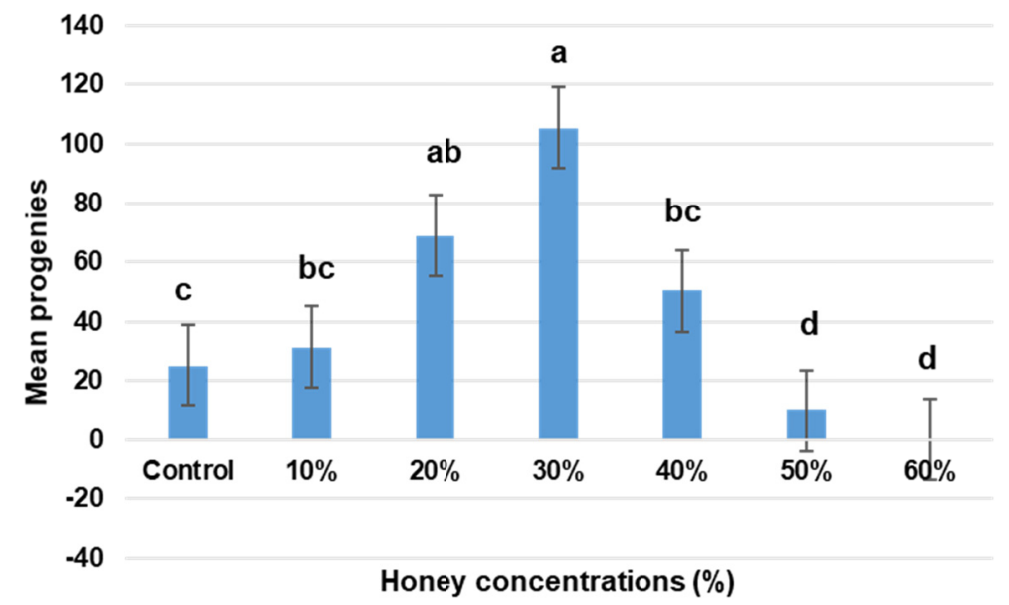

Figure 3. Comparison of different honey concentrations on number of Trichospilus pupivorus progenies. The bars are showing mean value of five replications. Error bars are showing Standard Error of means. Lettering on bars showing significant difference in treatments and similar letter showed no-significant difference computed with $\mathrm{P}=0.05$. The data were square-root transformed

\section{Discussion}

As mentioned previously, T. pupivorus survival rate was higher when fed with diluted honey as compared to distilled water. This could be attributed by the effect of carbohydrates content in the diluted honey which provides significant amount of energy than that of distilled water. It is supported by several other studies conducted by previous workers who tested numerous types of diets with higher content of carbohydates including honey than water and showed higher survival of parasitoids (Lahiri et al., 2017; Sigsgaard et al., 2013; Salmah et al., 2012). Aside from that, any excess calories which resulted in consumption of high-carbohydrate food, i.e., high honey concentration, would be converted into glycogen and triglycerides as energy reserve (Arrese \& Soulages, 2010). According to Berg et al. (2002), glycogen provide enough energy to sustain biological function for about 24 hours, whereas the triglyceride, a form of lipid, allow greater survival. This is proven by Kwang (2015) when he found that long-lived flies with 1:2 and 1:4 protein:carbohydrate ratio stored a greater amount of lipids than those short-lived ones.

Suitable honey concentrations for high survival may not be standard for all parasitoid species (Salmah et al., 2012; Harvey et al., 2012) but in the current study, the $30 \%$ honey concentration could be suitable enough for $T$. 
pupivorus to balance the amount of depleted and reserved energy. According to Bezerra et al. (2019), when hosts are unavailable for egg-laying, the survival of parasitoid was highly influenced by water and honey. Meanwhile, the reason of parasitoid's survival reduced largely in all of the treatments in later time could be due to the maximum feeding capacity of $T$. pupivorus that has been reached earlier in the experiment as the females might not have used all of their energy for egg-laying due to absence of the host. However, as other energy-demanding activities (i.e., flying, walking, reproduction, etc.) increased through time it caused the energy-reduced rapidly. Flying is an activity that requires high energy in most insects including hymenopteran (Suarez, 2000; Hedges, et al., 2019) and uses more carbohydrate reserves in the form of lipid. Thus, flying wasps need to feed more often than wasps resting most of the time.

Many researchers had reported that almost all parasitoid species had lived longer when provided with honey (Siekmann, 2002; Mitsunaga et al., 2004; Malati \& Hatami, 2010; Soyelu, 2013). This is probably because of the fact that honey contains various types of substances such as sugars, proteins, enzymes, amino acids, minerals and vitamins (Alvarez-Suarez et al., 2009) that is required by parasitoids for its survival. Azzouz et al. (2004) explained that the concentration of the diet solution primarily determines longevity, rather than the quantity of diet solution ingested. This is also agreed by Perera et al. (2019) when the highest longevity of Trichogrammatoidea bactrae (Hymenoptera: Trichogrammatidae) was recorded on 50\% honey. Shorter lifespan of T. pupivorus when fed with distilled water in this study is also the same to that observed for Cleruchoides noackae (Hymenoptera: Mymaridae) in which females lived only up to 1.7 days (Souza et al. (2016) and Diadegma semiclausum (Hymenoptera: Ichneumonidae) with 1.9 days (Winkler et al. 2009) when both fed with water. Aside from that, the reason of longer parasitoid longevity when fed with higher honey concentration could be that feeding on a high concentration of honey with higher viscosity (Kingslover \& Daniel, 1995) caused the parasitoid to feed only smaller amount of the diet (Siekman, 2001) and able to acquire more reserved energy to live longer as compared to lower concentration diets.

Parasitoid reproduction, another energy-demanding activity that requires lipid for its embryogenesis (Arrese \& Soulages, 2010), is highly determined by its food quality. This is also proven by Mashal et al. (2019) in their study when all tested diets containing honey had improved fecundity of three Trichogramma species (Hymenoptera: Trichogrammatidae). According to Benelli et al. (2017), the presence of optimal food sources which varies in amount and quality is considered helpful to improve parasitoid fertility and fecundity. The statement might have explained the reason for the increasing trend of progenies emergence when T. pupivorus were offered distilled water up to $30 \%$ honey concentration which later decreased when females were fed with higher honey concentrations $(40 \%, 50 \%$ and $60 \%$ ). The $30 \%$ honey could be the optimal food source in providing an adequate amount of nutrition required by $T$. pupivorus in its reproduction activity. Another alternative explanation could be that parasitoids fed on less concentrated honey (i.e., lower energy reserved), use more energy for reproduction due to perception of shorter lifespan as compared to those who fed higher honey concentration. This situation is most likely similar to Olson et al. (2000) in which starved females of Macrocentrus grandii (Hymenoptera: Braconidae) produced more eggs than sugar-fed females and they agreed that it was due to the lowered life expectancy. Apart from that, other factors such as type of sugar, temperatures, egg load capacity, adult maturity, adult size and others could also contribute towards the variability of progenies emergence. This is agreed by several workers when the egg load of the parasitoid was found to be correlated with diet concentrations (Bezerra et al., 2019), while temperatures also affected parasitoid emergence (Silva, et al., 2018). Thus, these factors could be potential characteristics to be considered and included in formulating an optimum diet for T. pupivorus.

In conclusion, the results of this study suggested that $30 \%$ honey concentration could be a suitable alternative food that could be used for rearing T. pupivorus. The higher survival of females during the early time elicited by this diet could also be an indication that the diet is probably suitable enough to balance the energy reserved and usage of the parasitoid. The highest number of progenies that emerged when fed with the $30 \%$ diet indicates that it could be used as an optimal food source in improving parasitoid's fertility. However, further investigations are required to ensure that other plausible factors affecting the reproduction and fitness of progenies such as host size, temperature, inter-specific competition and others are taken into consideration in formulating an optimum diet for the rearing of T. pupivorus.

\section{Acknowledgements}

Authors would like to thank MARDI for funding this activity under the Research and Development Fund. Special thanks to Mr Misbahul Khair and Mr Hazwan Kamaruzzaman for their continuous efforts throughout this study. 


\section{References}

Anantanarayanan, K. P. (1934). On the bionomics of a Eulophid (Trichospilus pupivora Ferr.) a natural enemy of the coconut caterpillar (Nephantis serinopa Meyr.) in South India. Bulletin of Entomological Research, 25(1), 55-61. https://doi.org/10.1017/S0007485300012505

Alvarez-Suarez, J., Tulipani, S., Romandini, S., Vidal, A. Y., \& Battino, M. (2009). Methodological aspects about determination of phenolic compounds and in vitro evaluation of antioxidant capacity in the honey: A review. Current Analytical Chemistry, 5, 293-302. https://doi.org/10.2174/157341109789077768

Arrese, E. L., \& Soulages, J. L. (2010). Insect fat body: Energy, metabolism, and regulation. Annual Review of Entomology, 55, 207-225. https://doi.org/10.1146/annurev-ento-112408-085356

APPPC (Asian and Pacific Plant Protection Commission). (1987). Insect pests of economic significance affecting major crops of the countries in Asia and the Pacific region (Technical Document No. 135). Bangkok, Thailand: Regional Office for Asia and the Pacific Region (RAPA).

Azzouza, B. H., Giordanengo, P., Wackersc, F. L., \& Kaisera, L. (2004). Effects of feeding frequency and sugar concentration on behaviour and longevity of the adult aphid parasitoid: Aphidius ervi (Haliday) (Hymenoptera: Braconidae). Biological Control, 31, 445-452. https://doi.org/10.1016/j.biocontrol.2004. 07.013

Baoqian, L., Zhenzheng, T., Glenn, B., Yiqiong, L., Zhenzheng, P., Qian, J., \& Haibo, W. (2016). Life table analysis under constant temperature for Opisina arenosella (Lepidoptera: Xyloryctinae) an invasive moth of palm plants. Austral Entomology, 55(3), 334-339. https://doi.org/10.1111/aen.12195

Benelli, G., Giunti, G., Tena, A., Desneux, N., Caselli, A., \& Canale, A. (2017). The impact of adult diet on parasitoid reproductive performance. Journal of Pest Science, 90, 807-823. https://doi.org/10.1007/ s10340-017-0835-2

Berg, J. M., Tymoczko, J. L., \& Stryer, L. (2002). Triacylglycerols are highly concentrated energy stores. In W. H. Freeman, (Eds.), Biochemistry (5th ed.). New York.

Bezerra Da Silva, C. S., Price, B. E., Soohoo Hui, A., \& Walton, V. M. (2019). Factors affecting the biology of Pachycrepoideus vindemmiae (Hymenoptera: Pteromalidae), a parasitoid of spotted-wing drosophila (Drosophila suzukii). PLoS ONE, 14(7), e0218301. https://doi.org/10/1371/journal.pone.0218301

DOA (Department of Agriculture Malaysia). (2018). Booklet Statistik Tanaman (Sub Sektor Tanaman Makanan) 2018 (p. 3). Malaysia: DOA Malaysia. Retrieved from http://www.doa.gov.my/index/resources/aktiviti sumber/sumber_awam/maklumat_pertanian/perangkaan_tanaman/booklet_statistik_tanaman_2018.pdf

DOA (Department of Agriculture Malaysia). (2019). Booklet Statistik Tanaman (Sub Sektor Tanaman Makanan) 2019 (p. 20). Malaysia: DOA Malaysia. Retrieved from http://www.doa.gov.my/index/resources/aktiviti sumber/sumber_awam/maklumat_pertanian/perangkaan_tanaman/booklet_statistik_tanaman_2019.pdf

Department of Agriculture Thailand. (2017). Regional training workshop on mass production of beneficial insects and nematodes. Thailand: Plant Protection Research and Development Office, DOA Thailand.

Dharmaraju, E. (1952). The biological control of the black headed caterpillar Nephantis serinopa M., in the East Godavari district of Madras State. Indian Coconut Journal, 4, 171-176.

Dharmaraju, E., \& Pradhan, S. (1976). Factors affecting the realisation of the biotic potential in Perisierola nephantidis Muesebeck and Trichospilus pupivora Ferriere, parasites of the coconut leaf caterpillar, Nephantis serinopa Meyrick. Indian Journal Entomology, 38, 370-376.

European and Mediterranean Plant Protection Organizastion. (2014). PQR database. Paris, France: European and Mediterranean Plant Protection Organization. Retrieved from http:/www.eppo.int/DATABASES/ pqr/pqr.htm

Ferriere, C. (1930). Notes on Asiatic chalcidoidea. Bulletin of Entomology Research, 21(3), $353-360$. https://doi.org/10.1017/S000748530002188X

Harvey, J. A., Cloutier, J., Visser, B., Ellers, J., Wackers, F. L., \& Gols, R. (2012). The effect of different dietary sugars and honey on longevity and fecundity in two hyperparasitoid wasps. Journal of Insect Physiology, 58, 816-823. https://doi.org/10.1016/j.jinsphys.2012.03.002 
Hedges, C. P., Wilkinson, R. T., Devaux, J. B. L., \& Hickey, A. J. R. (2019). Hymenoptera flight muscle mitochondrial function: Increasing metabolic power increases oxidative stress. Comparative Biochemistry and Physiology, Part A, 115-121. https://doi.org/10.1016/j.cbpa.2019.01.002

Jayaratnam, T. J. (1941). A study of the control of the coconut caterpillar, Nephantis serinopa Meyr. in Ceylon with special reference to its eulophid parasite, Trichospilus pupivora Ferr. Tropical Agriculturist, 96, 3-21.

Jin, T., Lin, Y. Y., Jin, Q. A., Wen, H. B., \& Peng, Z. Q. (2018). Design and selection of an artificial diet for the coconut black-headed caterpillar, Opisina arenosella, based on orthogonal array analysis. Journal of Integrative Agriculture, 17, 60345-60347. https://doi.org/10.1016/S2095-3119(17)61889-6

Jones, V. P., \& Westcott, D. (2002). The effect of seasonal changes on Nezara viridula (L.) (Hemiptera: Pentatomidae) and Trissolcus basalis (Wollaston) (Hymenoptera: Scelionidae) in Hawaii. Biological Control, 23,115-120. https://doi.org/10.1006/bcon.2001.0996

Kingsolver, J. G., \& Daniel, T. L. (1995). Mechanics of food handling by fluid-feeding insects. In R. F. Chapman, \& G. de Boer (Eds.), Regulatory mechanisms in insect feeding (pp. 32-53). Chapman and Hall. https://doi.org/10.1007/978-1-4615-1775-7_2

Kumar, M. G., Balasubramanian, G., \& Edward, Y. S. J. T. (1995). Life tables and intrinsic rate of natural increase of Trichospilus pupivorus population on different hosts. Madras Agriculture Journal, 82(6, 7, 8), 483-485.

Kumar, R. (2002). Studies on ecology, reproductive biology and management of Opisina arenosella Walker (Lepidoptera: Oecophoridae) (PhD Thesis. University of Agricultural Sciences, Bengalore, India).

Kumara, A. D. N. T. (2015). Electrophysiological and behavioural responses of coconut black-headed caterpillar, Opisina arenosella Walker (Lepidoptera: Oecophoridae) to semiochemicals (PhD Thesis. University of Agricultural Sciences, Bengalore, India). https://doi.org/10.1007/s12600-015-0481-2

Kwang, P. L. (2015). Dietary protein: carbohydrate balance is a critical modulator of lifespan and reproduction in Drosophila melanogaster: A test using a chemically defined diet. Journal of Insect Physiology, 75, 12-19. https://doi.org/10.1016/j.jinsphys.2015.02.007

Lahiri, S., Orr, D., Cardoza, Y. J., \& Sorenson, C. (2017). Longevity and fecundity of the egg parasitoid Telenomus podisi provided with different carbohydrate diets. Entomologia Experimentalis et Applicata, 162,178-187. https://doi.org/10.1111/eea.12531

Malati, A. K., \& Hatami, B. (2010). Effect of feeding and male presence on some biological characteristics of female Trichogramma brassicae (Hymenoptera: Trichogrammatidae). Journal of Entomology Society Iran, 29(2), 1-11.

Mashal, S., Agamy, E., Abou-bakr, H., Abdel Wahab, T. E., \& El Behery, H. (2019). Effect of honeybee products, as food supplements, on the biological activities of three Trichogramma species (Hymenoptera: Trichogrammatidae). Egyptian Journal of Biological Pest Control, 29(46), 1-8. https://doi.org/10.1186/ s41938-019-0149-1

Mitsunaga, T., Shimoda, T., \& Yano, E. (2004). Influence of food supply on longevity and parasitization ability of a larval endoparasitoid, Cotesia plutellae (Hymenoptera: Braconidae). Applied Entomology and Zoology, 39(4), 691-697. https://doi.org/10.1303/aez.2004.691

Mohan, C., Radhakrishnan Nair, C. P., Kesavan Nampoothiri, C., \& Rajan, P. (2010). Leaf-eating caterpillar (Opisina arenosella)-induced yield loss in coconut palms. International Journal of Tropical Insect Science, 30(3), 132-137. https://doi.org/10.1017/S174275841000024X

Murthy, K., \& Jalai, S. K. (2003). Evaluation of artifical diets for coconut blackheaded caterpillar, Opisina arenosella Walker. Annals Plant Protection Science, 11(1), 20-22.

Narendran, T. C. (2011). Fauna of India and adjacent countries. Eulophinae (Hymenoptera: Eulophidae). Kolkata, India: Zoological Survey of India.

Nirula, K. K. (1956). Investigations on the pests of coconut palm. Part III. Nephantis serinopa Meyrick, control. Indian Coconut Journal, 9,174-201.

Nor Ahya, M., \& Tajul Ariffin, A. Y. (2018). A first record of incidence of new invasive moth Opisina arenosella on coconut in Malaysia (pp. 92-97). Proceeding of National Coconut Conference 2018, August 7-9, 2018, Kinta Riverfront Hotel \& Suite Ipoh, Perak. 
Nor Ahya, M., Tajul Ariffin, A. Y., \& Rozeita, L. (2019). Searching and parasitism behaviour of Trichospilus pupivorus (Hymenoptera: Eulophidae), a potential parasitoid of coconut black-headed caterpillar Opisina arenosella (Lepidoptera: Oecophoridae). Serangga, 24(1), 80-90.

Olson, D. M., Fadamiro, H., Lundgren, J. G., \& Heimpel, G. E. (2000). Effects of sugar feeding on carbohydrate and lipid metabolism in parasitoid wasp. Physiological Entomology, 25, 17-26. https://doi.org/10.1046/ j.1365-3032.2000.00155.x

Perera, M. C. D., \& Hemachandra, K. S. (2014). Study of longevity, fecundity and oviposition of Trichogrammatoidea bactrae Nagaraja (Hymenoptera: Trichogrammatidae) to facilitate mass rearing. Tropical Agricultural Research, 25(4), 602 - 609. https://doi.org/10.4038/tar.v25i4.8065

Rao, Y. R., Cherian, M. C., \& Anantanarayanan, K. P. (1948). Infestations of Nephantis serinopa Meyr., in South India and their control by the biological method. Indian Journal of Entomology, 10, 205-247.

Remadevi, O. K., Abdurahiman, U. C., Mohamed, U. V. K., \& Beena, C. G. (1980). Biology and behaviour of Trichospilus pupivora (Hymenoptera: Eulophidae) with a note on its field parasitism of Nephantis serinopa (Lepidoptera: Xylorictidae). Ceylon Coconut Quartelity, 31, 19-126.

Salmah, M., Basri, M. W., \& Idris, A. B. (2012). Effects of honey and sucrose on longevity \& fecundity of Apanteles metesae (Nixon), a major parasitoid of the oil palm bagworm, Metisa plana (Walker). Sains Malaysiana, 41(12), 1543-1548.

Santhosh Babu, P. B. (1989). Studies on some aspects of reproduction in male Opisina arenosella Walker (Insecta: Lepidoptera: Xyloryctinae) (PhD Thesis, University of Kerala, Trivandrum, India).

Sathe, T. V., \& Chougale, T. M. (2014). Hymenopterous biopesticides and their preliminary biocontrol potential from Western Maharshtra including Ghats. Biolife, 2(4), 1254-1261.

Shameer, K. S., Nasser, M., Mohan, C., \& Hardy, I. C. W. (2017). Direct and indirect influences of intercrops on the coconut defoliator Opisina arenosella. Journal of Pest Science, 91(1), 259-275. https://doi.org/10.1007/ s10340-017-0904-6

Siekmann, G., Tenhumberg, B., \& Keller, M. A. (2001). Feeding and survival in parasitic wasps: sugar concentration and timing matter. Oikos, 95, 425-430. https://doi.org/10.1034/j.1600-0706.2001.950307.x

Siekmann, G. (2002). Food foraging in adult parasitoid Cotesia rubecula: How sugar sources contribute to survival and reproduction ( $\mathrm{PhD}$ Thesis. Adelaide University, Australia).

Sigsgaard, L., Betzer, C., Naulin, C., Eilenberg, J., Enkegaard, A., \& Kristensen, K. (2013). The effect of floral resources on parasitoid and host longevity: Prospects for conservation biological control in strawberries. Journal of Insect Science, 13(104), 1-17. https://doi.org/10.1673/031.013.10401

Silva, I. M., Pereira, K. D. S., Spranghers, T., Zanuncio, J. C., \& Serrao, J. E. (2016). Antennal sensilla and sexual dimorphism of the parasitoid Trichospilus pupivorus (Hymenoptera: Eulophidae). Microscopy and Microanalysis, 22, 913-921. https://doi.org/10.1017/S1431927616011314

Silva, G. V., Bueno, A. F., Janeiro Neves, P. M. O., \& Favetti, B. M. (2018). Biological characteristics and parasitism capacity of Telenomus podisi (Hymenoptera: Platygastridae) on eggs of Euschistus heros (Hemiptera: Pentatomidae). Journal of Agricultural Science, 10(8), 210-220. https://doi.org/10.5539/jas. v10n8p210

Souza, A. R., Candelaria, M. C., Barbosa, L. R., Wilcken, C. F., Campos, J. M., Serrão, J. E., \& Zanuncio, J. C. (2016). Longevity of Cleruchoides noackae (Hymenoptera: Mymaridae), an egg parasitoid of Thaumastocoris peregrinus (Hemiptera: Thaumastocoridae), with various honey concentrations and at several temperatures. Florida Entomologist, 99(1), 33-37. https://doi.org/10.1653/024.099.0107

Soyelu, O. J. (2013). Suitability of a novel diet for a parasitic wasp, Cotesia plutellae. Journal of Insect Science, 13, 86. https://doi.org/10.1673/031.013.8601

Stoffolano, J. G. Jr. (1995). Regulation of a carbohydrate meal in the adult Diptera, Lepidoptera, and Hymenoptera. In R. F. Chapman, \& G. de Boer (Eds.), Regulatory mechanics in insect feeding (pp. 210-240). Chapman and Hall. https://doi.org/10.1007/978-1-4615-1775-7_8

Suarez, R. K. (2000). Energy metabolism during insect flight: Biochemical design and physiological performance. Physiological and Biochemical Zoology, 73(6), 765-771. https://doi.org/10.1086/318112 
Tavares, W. S., Hansson, C., Serrão, J. E., \& Zanuncio, J. C. (2012). First report of Trichospilus pupivorus (Hymenoptera: Eulophidae) parasitizing pupae of Anticarsia gemmatalis (Lepidoptera: Noctuidae). Entomology Generalis, 33(4), 281- 282. https://doi.org/10.1127/entom.gen/33/2012/281

Tavares, W. S., Hansson, C., Serrão, J. E., \& Zanuncio, J. C. (2013). Trichospilus pupivorus (Hymenoptera: Eulophidae): First report of parasitism on Thagona tibialis (Lepidoptera: Lymantriidae) in Brazil. Studies on Neotropical Fauna and Environment, 48(2), 104-105. https://doi.org/10.1080/01650521.2013.837348

Winkler, K., Wäckers, F. L., Kaufman, L. V., Larraz, V., \& van Lenteren, J. C. (2009). Nectar exploitation by herbivores and their parasitoids is a function of flower species and relative humidity. Biological Control, 50, 299-306. https://doi.org/10.1016/j.biocontrol.2009.04.009

\section{Copyrights}

Copyright for this article is retained by the author(s), with first publication rights granted to the journal.

This is an open-access article distributed under the terms and conditions of the Creative Commons Attribution license (http://creativecommons.org/licenses/by/4.0/). 